\title{
THE CRACKED FOUNDATIONS OF THE RIGHT TO SECEDE
}

\author{
Donald L. Horowitz
}

Donald L. Horowitz is James B. Duke Professor of Law and Political Science at Duke University, and author, most recently, of The Deadly Ethnic Riot (2001). He is currently working on a study of constitutional design for divided societies. The present essay is based on a paper presented at a conference at Boston University, funded by the Smith Richardson Foundation, on "Partitions as a Solution to Ethnic Conflict."

Many things changed with the end of the Cold War. One of the main changes is the new enthusiasm for public international law. In a world freed of an overwhelming rivalry of two great power blocs, but by no means freed of conflict, it became possible to think of a qualitatively enhanced role for the rule of law in the regulation of international relations. Nowhere has this thinking been more evident than in the regulation of conflict and warfare between ethnic groups. Two main prongs of international legal activity are the establishment of tribunals to punish genocide and crimes against humanity and the elaboration of various doctrines of human rights, including a possible right of ethnic groups to secede from states in which they are located. This asserted right, which would be a reversal of existing international law, is, in my view, ill considered.

The newly asserted right to secede is to be held by ethnic groups and is derived from a reinterpretation of the principle of the self-determination of nations. Theorists display varying degrees of enthusiasm in their advocacy of such a right, but all of them, whether they would permit secession generously or only reluctantly after certain conditions have been fulfilled, see secession as an answer to problems of ethnic conflict and violence. The position I shall take here is that secession is almost never an answer to such problems and that it is likely to make them worse. The proposals, in short, are not informed by any serious understanding of patterns of ethnic conflict or ethnic-group political behavior.

Secession, I shall argue, does not create the homogeneous successor 
states its proponents often assume will be created. Nor does secession reduce conflict, violence, or minority oppression once successor states are established. Guarantees of minority protection in secessionist regions are likely to be illusory; indeed, many secessionist movements have as one of their aims the expulsion or subordination of minorities in the secessionist regions. The very existence of a right to secede, moreover, is likely to dampen efforts at coexistence in the undivided state, including the adoption of federalism or regional autonomy, which might alleviate some of the grievances of putatively secessionist minorities. Since most secessionist movements will be resisted by central governments and most secessionists receive insufficient foreign military assistance to succeed, propounding a right to secede, without the means to success, is likely to increase ultimately fruitless secessionist warfare, at the expense of internal efforts at political accommodation and at the cost of increased human suffering. Efforts to improve the condition of minorities ought to be directed at devising institutions to increase their satisfaction in existing states, rather than encouraging them to think in terms of exit options. In those rare cases in which separation of antagonists is, at the end of the day, the best course, partition can be accomplished reluctantly, as a matter of prudence, without recognizing a right to secede. But neither partition nor secession should be viewed as generally desirable solutions to the problems of ethnic conflict.

\section{Secession and Self-Determination: A Brief Sketch}

The so-called right to secede has its origins in the principle of national self-determination. As is well known, that principle formed an integral part of Woodrow Wilson's plans for post-World War I Europe. The establishment of, for example, Rumania as a state for Rumanians certainly exemplified application of the self-determination principle, but, even apart from the presence of minorities in such new states, the Wilsonian policy fell far short of according national or ethnic groups their own states. Indeed, Wilson may well have envisioned autonomy rather than independence, and he did not necessarily think in terms of an ethnic fulfillment for the right to self-determination. Yugoslavia and Czechoslovakia, for example, were multinational states, and Wilson's proposal that a right of self-determination be incorporated in the Covenant of the League of Nations was rejected. By the time of the Atlantic Charter in 1941, self-determination was to be limited to peoples living under foreign domination. ${ }^{1}$ Decolonization was thus an exercise of selfdetermination, and it was soon made clear by the United Nations (in 1960) and the Organization of African Unity (in 1964), among others, that secessionist threats to the territorial integrity of states would not be regarded as further exercises of self-determination.

With the exception of decolonization and the extraordinary emergence 
of Bangladesh, territorial boundaries proved to be remarkably stable for a half century: from just after World War II to the end of the Cold War. ${ }^{2}$ And then a concatenation of events-the reunification of Germany, the dissolution of the Soviet Union (and various sub-secessions in Georgia, Moldova, and Azerbaijan), Yugoslavia, and Czechoslovakia, the secession of Eritrea from Ethiopia and of the former Somaliland from Somalia, and finally the de facto detachment of Kosovo from Serbia-combined in the course of a decade to render boundaries much less stable and to encourage territorially separate groups to consider the possibility of secession.

As all this was happening, international lawyers and philosophers had been rethinking the meaning of self-determination and proceeding to unsettle the former understandings that had discouraged secession and international support for it. One practical exercise along these lines was the ill-considered decision of the Badinter Commission that, asked to pronounce on the validity of secessions from Yugoslavia, declared Yugoslavia to be a federation in process of dissolution-a state of affairs that entitled its constituent republics to secede intact, taking with them their minority areas. ${ }^{3}$ After this decision, many fewer states than should consider adopting a federal form of government will do so.

Most of the work of international lawyers has been, however, theoretical. It proceeds along several lines.

For some, self-determination forms an integral part of the right of people to choose their own political regime and to be free of authoritarian oppression. (For Wilson, too, self-determination was connected to ideas of popular sovereignty.) It is a building block of what was emerging in the thinking of a few international lawyers as a right to live under a democratic regime. ${ }^{4}$ That such a legal right is at best aspirational might be suggested by the fact that more than half of all regimes in the world are still not democratic, but the early aftermath of the Cold War was a time of great optimism.

Equally expansive are justifications of secession that rest on the right of people in general or people with common group characteristics to choose those with whom they wish to associate politically. ${ }^{5}$ Among philosophers who have endorsed the right of ethnic groups to secede, most have begun from the premise that self-determination is to ethnic groups what moral autonomy is to individuals. As individuals have rights to political self-expression, so, too, do groups; and for groups, selfexpression means self-government, which, in the era of the territorial state, implies control of territory. ${ }^{6}$

The analogy of collective self-determination to individual autonomy is entirely specious. For one thing, collective identity fluctuates, as individual identity does not. New groups come into being, and old ones merge or divide. No new political entity can solve the problem of collective self-expression, as Pakistanis, divided in 1947, redivided in 1971, and 
still dividing further, have long since discovered. Moreover, even at the outset, the minorities problem is not a trivial detail in recognizing secessions; it is, instead, the central reason why the idea of a clean break is a chimera.

A more cautious version of the right to secede is espoused by those who view secession principally as a "remedial right,"7 a last-ditch response to discrimination or oppression by a central government. ${ }^{8}$ If interethnic accommodation fails and one portion of a population is "unalterably hostile" to a group of its fellow citizens, then, it is said, "republican theories may support political divorce on the ground that separation would produce two states in which republican democracy is viable instead of one that lacks essential preconditions to its successful practice."

Despite important differences in scope and reasoning among these justifications for secession, there is a substratum of assumptions in all of them. Secession, it is assumed, can produce homogeneous successor states. In those cases in which heterogeneity remains, it is asserted, minority rights can nevertheless be guaranteed. Like the Badinter Commission, most writers advocating a right to secede make no provision for further secessions, except, of course, insofar as infinite regress of secessionist rights may be implied in their formulations. Secession will also, it is assumed, result in a diminution of conflict that produced the secessionist movement. Rarely are these assumptions discussed or even rendered explicit, but they are essential to the analysis.

"If you can think about something which is attached to something else without thinking about what it is attached to, then you have what is called a legal mind." 10 So pronounced the late constitutional lawyer, Thomas Reed Powell, three-quarters of a century ago. Most theorists of a right to secession have, in this caricatured sense, legal minds. They have generally not concerned themselves with the ethnic politics that produces secessionist claims and that will be affected by new rights to secede. It is no accident that most people who do study ethnic politics are decidedly less enthusiastic about secession than are the international lawyers and philosophers who are the main proponents of a right to secede.

\section{Heterogeneity Before, Heterogeneity After}

There are always ethnic minorities in secessionist regions. There were Efik and Ijaw, among others, in Biafra; there are Hindus in Kashmir, Muslims in Tamil areas of Sri Lanka, Javanese in Aceh and Irian Jaya, Serbs and Roma in Kosovo; and there are minorities in all the rump states as well. As a matter of fact, it is often the desire of regional majorities to deal with minorities - and not to deal with them in a democratic way-that motivates or contributes to the secessionist movement in the first instance. Proponents of rights to secession assure us that minority rights must be guaranteed in secessionist states and that secession should 
be less favored if minority rights are unlikely to be respected, ${ }^{11}$ but the verbal facility of this formulation masks the difficulty of achieving any such results. If, after all, conditions on the exercise of an international law right to secede can be enforced, why not enforce those conditions in the undivided state so as to forestall the need to secede? International law has been notoriously ineffective in assuring longstanding, internationally recognized minority rights, and proponents of secession have no new ideas to offer on this matter. If the failure to respect minority rights in the undivided state induced a regional group to consider secession, why should anyone assume that the situation will be different when that group, a minority in the undivided state, comprises a majority in the secessionist state? If anything, the treatment of minorities in smaller states is less visible to outsiders.

The more circumscribed the asserted right to secede, ironically enough, the more dangerous conditions may become for minorities in the secessionist region. By the time it is concluded that the majority in the undivided state is unalterably hostile to minority interests, thus in some formulations permitting the minority to secede, that group may have accumulated so many grudges that, in their turn, minorities in the secessionist region may be particularly vulnerable to the expression of violent hostility or the settlement of old scores. There are many examples: the fate of Serbs and Roma in Kosovo, of Biharis in Bangladesh, of Sikhs and Hindus in Pakistan at the time of partition, and of Muslims in India at the same time. If the problem of minorities is that they do not enjoy "meaningful political participation" ${ }^{2}$ in the undivided state, there is no reason to think that minorities will enjoy it in the secessionist state either. Secession merely proliferates the arenas in which the problem of intergroup political accommodation must be faced-and often more starkly. Contrast Yugoslavia, with six or seven groups and the complex alignments they created with Bosnia, in which three groups confront each other. Secession can hardly be said to solve the problem of intergroup accommodation, except, of course, insofar as it enables the former minority, now a new majority, to cleanse the secessionist state of its minorities-which it could not do previously-and induces the rump state to do the same with members of the secessionist group who find themselves left on the wrong side of a new international boundary.

\section{The Effect of New International Boundaries}

Recognition of a right to secede is thus not likely to be the end of an old bitterness but the beginning of new bitterness. It is, of course, easy to question whether a slavish devotion to territorial integrity is still appropriate. There has been a great deal of loose talk about the allegedly artificial character of many international boundaries and the part played by colonial convenience in settling them. In point of fact, even in 
Africa, where this charge is most frequently encountered, boundaries were not settled as disrespectfully of ethnic patterns as is frequently asserted. ${ }^{13}$ In any event, patterns of settlement are such that virtually any boundaries would have a large element of arbitrariness to them. Secession would not be a way of rectifying boundaries, because there are no truly natural boundaries.

If it does not solve boundary problems, secession does do something else. A secession or partition converts a domestic ethnic dispute into a more dangerous international one. And since states are able to procure arms with few of the restraints that periodically bedevil insurgents, the international dispute often involves escalating weapons and the prospect of international warfare. Consider the nuclear armaments possessed by India and Pakistan and the recurrent warfare between those states.

One reason for the greater danger that often follows secession is the activation of irredentist claims. For reasons I have explicated elsewhere, ${ }^{14}$ the serious pursuit of irredentas-movements to retrieve kindred people and their territory across international boundaries-has been relatively rare in the post-World War II world. But successful secession or partition is likely to change this benign state of affairs. Either the rump state or the secessionist state will desire to retrieve minorities stranded on the wrong side of the border. There are examples readily at hand: Kashmir, Serb claims in Bosnia and in the Krajina region of Croatia, warfare between Ethiopia and Eritrea. And when irredentism gets going, it usually involves ethnic cleansing, so as to eliminate troublesome minorities in the region to be retrieved. A recent quantitative study of the effects of partition finds that partition does not prevent further warfare between ethnic antagonists, and it has only a negligible (and easily reversed) positive effect on low-grade violence short of war. ${ }^{15}$

The recurrent temptation to create a multitude of homogeneous ministates, even if it could be realized, might well increase the sum total of warfare, rather than reduce it. The right direction for international boundaries is upward, not downward, so that states are so heterogeneous that no one group can plausibly dominate others. ${ }^{16}$ Although this degree of benign ethnic complexity is exceedingly difficult to achieve, it is still true that India, with its many groups, is a better model than Kosovo or Rwanda, with just two or three.

\section{Secession Rights and Internal Accommodation}

Articulating a right to secede will undermine attempts to achieve interethnic accommodation within states. As things now stand, the principal reason that states are reluctant to devolve power to territorially concentrated minorities, either by means of regional autonomy or federalism, is their fear that it will lead to secession. That fear is usually unfounded, unless the conflict has already dragged on for a long time and the central 
government has been utterly ungenerous. Nevertheless, central governments are risk averse about devolution. The best way to dry up devolution as a tool of interethnic accommodation-and a promising tool it is-is to establish a right, recognized in international law, for territorially concentrated minorities to secede. If there is a well-recognized right to secede, the first stirrings of territorially based ethnic discontent will be likely to be met with repression. The possibility that federalism or regional autonomy can lawfully ripen into secession will make any such experiment too costly to entertain. It has been difficult to persuade central decision makers in Indonesia and Sri Lanka to devolve power to regions. A right to secession would easily dissuade them.

One reason central governments are so reluctant to countenance the possibility of secession, even for troublesome regions that some central decision makers might wish to be free of, is that the secession of one region upsets ethnic balances and forces groups in other regions to think afresh about whether they wish to remain in the truncated state with its new ethnic balances. This was clearly visible in Yugoslavia after the Slovene and Croat decisions to secede, when others had to decide in turn whether the relative expansion in Serb power in the rump state was in their interest. Yoruba narrowly decided to stay in Nigeria, despite the relative increase in Hausa power when Ibo decided to leave the state in 1967, and the departure of East Bengal (Bangladesh) from Pakistan destabilized relations among the groups that remained in the rump state. Quite often the fears of central authorities about secession are derided as unsubstantiated apprehensions of domino effects. But domino effects are usually conceived as action based merely on a successful example in another location, whereas what is involved in the first secession is action that affects directly, rather than just by example, the relative positions of other groups remaining in the state.

The creation of a right to secede could not be more untimely. More and more states have been designing internal political arrangements, including devolution, to reduce the incidence of ethnic conflict. That is where the emphasis needs to be, not on making exit strategies more plausible. More about this shortly.

A right to secede effectively advantages militant members of ethnic groups at the expense of conciliators. Since most central governments will not recognize the right to secede, those who wish to pursue such a course will need to resort to arms. Those who are willing to resort to arms are by no means simply latter-day versions of the politicians of their own group whom they seek to displace. Contrast Hashim Thaci of the Kosovo Liberation Army with the Kosovar political leader Ibrahim Rugova; Prabhakaran of the Tamil Tigers with Amirthalingham of the Tamil United Liberation Front, whom he had assassinated; the Southern People's Liberation Army in the Sudan with the old Liberal Party that preceded it. Violence disproportionately attracts people with 
an interest in aggression. The people willing to take up arms for secession are those who are willing to be brutal with their ethnic enemies and with their own rivals as well. As their advantage grows, new bouts of ethnic cleansing can be expected.

In some formulations, secession is said to be an "exceptional" right that "comes into play if" it "is the only way that a defined population can exercise its right of internal self-determination." 17 But the facts do not support the assumption that secession is ever "the only way." Are the Kurds in Iraq secessionist or autonomist? They have gone back and forth. Are Philippine Muslims? They, too, have gone back and forth. Ibo tried unsuccessfully to secede and then reintegrated into Nigerian politics. In such cases, it looks to outsiders at any given moment as if secession is "the only way" minorities can participate in determining their own future, but there is more fluidity to ethnic politics than those who write about populations that are "unalterably hostile" 18 to each other have sensed.

Moreover, the seemingly moderate position of some proponents of a right to secession that secession is justified only if others are unalterably opposed or minorities have been victimized is not likely to work out moderately in practice, for it is an incentive to ethnic polarization. If independence can only be won legitimately after matters have been carried to extremes, then, by all means, there are people willing to carry them to extremes. In the 1980s and early 1990s, Sikh separatists in the Indian Punjab were willing to attack Hindus in order to precipitate attacks on Sikhs elsewhere in India. There is no shortage of methods to satisfy tough standards of victimization or oppression. A right to secede could indeed contribute to the sense that secession is the only way.

There may be times when it is felt best to part peoples. The British believed such a time had come in India in 1947, and the United Nations believed such a time had come a year later in Palestine. When it is prudent, parting can be done by consent, as in the former Soviet Union and in Czechoslovakia, or occasionally by international action. To do this requires the creation of no rights.

Consider the pernicious effect on the balance of intragroup opinion of a right to secede in a concrete case: Sri Lanka. Will the Sri Lankan Tamils return as readily as they would otherwise to a thoroughly reconstructed but undivided Sri Lanka if they discover that the secession to which they turned so reluctantly was merely an exercise of their rights under international law? It is always hard for antagonistic groups to accommodate each other in a single state. A right to secede will make it harder.

\section{The Case for Humility in Public International Law}

As I indicated at the outset, rights to secession are only in some formulations grounded in the extreme oppression of minorities. In others, 
rights to secede derive from the alleged commitment of international law to democracy. In fact, international law has not had a particularly deep or longstanding commitment to democracy. Only in 1992 did Thomas Franck purport to discover an "emerging entitlement" to be governed democratically. ${ }^{19}$ International law has always placed great emphasis on the writings of jurists, but traditionally for their syntheses of legal rules and for their influence on state practice that could then change the law, not for the direct creation of new rights by cobbling together new formulations. Such a practice is particularly doubtful when it is recalled that international law is a field in which judicial and bureaucratic institutions far outrun representative ones.

In 1998, the British jurist James Crawford produced a long and exhaustive survey of state practice and the international law pertaining to secession. ${ }^{20}$ Crawford's conclusion was simply stated:

... State practice since 1945 shows very clearly the extreme reluctance of States to recognize or accept unilateral secession outside the colonial context. That practice has not changed since 1989, despite the emergence during that period of 22 new States. On the contrary, the practice has been powerfully reinforced. ${ }^{21}$

Bangladesh, Crawford noted, was best viewed not as exemplar of a recognized right to secede but "rather as a fait accompli achieved as a result of foreign military assistance in special circumstances."22 Other cases, such as Eritrea and the Baltic states, involved mutual consent. Where central governments oppose unilateral secession, Crawford found, the secessionists gain little or no international recognition. This certainly has been the case in northern Somalia and Transdniestria, among others. And, finally, there is "no recognition of a unilateral right to secede based merely on a majority vote of the population of a given subdivision or territory. In principle, self-determination for peoples or groups within the State is to be achieved by participation in its constitutional system, and on the basis of respect for its territorial integrity." ${ }^{23}$

Crawford might have, but did not, note the contrary but truly exceptional position of the government of the United Kingdom, which has stated, in ways meant to be binding, that a majority of the people of Northern Ireland might vote to dissolve their union with Britain and to join the Irish Republic instead. But this has not been the position of other states, and it is not the position of the United Kingdom with respect to Scotland or Wales.

If a right to secede is a by-product of an emerging right to democratic governance, there is not much evidence of it. Subtract the Franck formulation and a somewhat earlier one by Cassese ${ }^{24}$ and the dedication of international law to democratic governance becomes much thinner. What little there is mainly is confined to writers, rather than custom, state practice, treaties, or court decisions. 
Why the connection of international law to democratic governance is so thin should be very clear. However much we may favor the worldwide spread of democracy - and I have done my time trying to spread democratic institutions to reduce ethnic conflict—valorizing a right to democratic governance would imperil the universality of international law. Despite the developments of the post-Cold War period, there are almost as many authoritarian as democratic states. If international law is to enhance its influence on state behavior, which it needs to do in order to reduce and regulate interstate conflict and to facilitate interstate transactions, it cannot simultaneously undercut the governing arrangements of nearly half the states that are to be subjected to the rules laid down. ${ }^{25}$

There is, of course, an even more obvious reason why international law ought to be exceedingly restrained in its enthusiasm for secession. Secession is an anti-state movement, and an international law that forgets that states are its main subjects risks its own survival.

There is always a tendency of law to preempt social complexity with rules, and there are many temptations to the promiscuous creation of rights. But law does best when it is informed by what Karl Llewellyn called "situation sense," 26 a sound idea of the type of phenomenon it seeks to govern. If self-determination is a phrase "simply loaded with dynamite," ${ }^{27}$ in the words of Wilson's secretary of state, there are international lawyers who are playing with this dynamite.

\section{Living With Heterogeneity}

I said earlier that emphasis needs to be on fostering interethnic accommodation within states. The choice between secession or partition, on the one hand, or murderous conflict, on the other, is a false choice. Institutions can mitigate conflict. This is much too large a topic to discuss at length here, but, since I have been so critical of those who have readily endorsed the right of ethnic groups to leave states, it is incumbent on me at least to sketch briefly what some alternatives might look like.

Most states are ethnically heterogeneous, and many are severely divided. Many groups seek to treat the state as an ethnic patrimony, as if it were homogeneous or as if they had a prior claim to legitimacy and others were there merely on sufferance. Why this is so is a complicated story. Despite these depressing tendencies-which are highly variable rather than universal-it is long past the time when ethnic kinship could form the foundation for homogeneous communities. Territorial proximity is now an inescapable basis for political community.

In general terms, there are two competing prescriptions for solving the problem of ethnic conflict in a democratic framework. Each has its proponents and detractors, its strong and weak points.

The first prescription goes by the name of consociational democracy: 
a formula for government by grand coalition of all groups, for minority vetoes on important policy issues, for ethnic proportionality in cabinet positions, civil-service posts, and financial allocations, and for cultural autonomy for all groups as well. ${ }^{28}$ Many criticisms have been made of consociational theory, for its neglect of democratic opposition (if everyone is in a grand coalition, where will opposition come from?) and its alleged propensity for excessively limited government and immobilism. My own criticism is that grand coalitions are impossible where divisions are severe, because the very formation of such a coalition produces opposition based on the accusation that group interests have been sold out. Moreover, consociation is essentially a system of guarantees, and so is attractive to minorities, but not to majorities, who prefer majority rule. As a result, there are consociational features adopted occasionally by states, but few full-blown consociational regimes. Grand coalitions and minority vetoes are particularly scarce.

My own preferred course involves the use of political incentives to encourage interethnic moderation. There are various institutions, particularly electoral systems, that are capable of inducing moderate behavior on the part of politicians. If election depends, at the margin, on the ability to gain some votes from members of groups other than one's own, then political leaders will behave in an ethnically conciliatory fashion for that purpose. ${ }^{29}$ One thing we know is that politicians like being elected and reelected. If consociational theory provides no motive for compromise behavior, incentive theory, by definition, does not share that defect.

Yet there are obstacles to the adoption of incentives schemes as well. Although one can find incentive-based devices adopted by states, a full ensemble of institutions containing incentives to foster conciliation is not easy to find.$^{30}$ There is evidence that these devices work, but what are the incentives to adopt the incentives?

Often, processes of bargaining over institutions produce compromises that dilute the effect that could have been expected, had there been a more thoroughgoing and consistent set of institutional changes. Still, partial adoptions can have some positive effect on conciliation.

The upshot of the problem of adoption is that most severely divided societies will not soon become dramatically more harmonious. Over time, some have, and others will, but not necessarily wholly as a result of political engineering. Political engineering will play its part, a greater part at certain unusually propitious times (and such moments should be seized), but the difficulty of wholesale adoption means that many societies will muddle along, sometimes severely conflicted, sometimes better able to achieve compromise if their partial adoption of conciliatory devices is well considered. But, for present purposes, what needs to be emphasized is that efforts at conciliation will not be helped by providing either a liberal or a constrained right to secede. There is an inevitable 
tradeoff between encouraging participation in the undivided state and legitimating exit from it. The former will inevitably produce imperfect results, but the latter is downright dangerous.

\section{NOTES}

1. See the excellent entry by Michael Banton, "Self-Determination," in Athena Leoussi, ed., Encyclopaedia of Nationalism (New Brunswick, N.J.: Transaction Publishers, 2001), 271-73.

2. The so-called secession of Singapore was actually an expulsion of the city-state from Malaysia and was portrayed in legal instruments as occurring by mutual consent.

3. Opinions of the Arbitration Committee, reported by Alain Pellet, "The Opinions of the Badinter Arbitration Committee: A Second Breath for the Self-Determination of Peoples," European Journal of International Law 3 (1992): 178, Appendix, at 183.

4. See Thomas M. Franck, "The Emerging Right to Democratic Governance," American Journal of International Law 86 (January 1992): 46-91. See also Antonio Cassese, "Political Self-Determination: Old Concepts and New Developments," in Antonio Cassese, ed., UN Law/Fundamental Rights: Two Topics in International Law (Alphanaanden Rijn, Netherlands: Sijthoff and Noordhoff, 1979), 137-65; and Morton H. Halperin and Kristen Lomasney, "Toward a Global 'Guarantee Clause," Journal of Democracy 4 (July 1993): 60-69.

5. See for example Daniel Philpott, "Self-Determination in Practice," in Margaret Moore, ed., National Self-Determination and Secession (Oxford: Oxford University Press, 1998), 79-102.

6. For surveys of such theories, see Donald L. Horowitz, "Self-Determination: Politics, Philosophy, and Law," in Margaret Moore, ed., National Self-Determination and Secession, 197-200; and Allen Buchanan and David Golove, "The Philosophy of International Law," in Jules Coleman and Scott Shapiro, eds., The Oxford Handbook of Jurisprudence and Philosophy of Law (Oxford: Oxford University Press, 2002).

7. See Allen Buchanan and David Golove, "The Philosophy of International Law." See also Allen Buchanan, Secession: The Morality of Political Divorce from Fort Sumter to Lithuania and Quebec (Boulder, Colo.: Westview, 1991); and Diane F. Orentlicher, "International Responses to Separatist Claims," paper presented at the Annual Meeting of the American Society for Political and Legal Philosophy, San Francisco, 2-3 January 2001.

8. Robert McCorquodale, "Human Rights and Self-Determination," in Mortimer Sellers, ed., The New World Order: Sovereignty, Human Rights, and the Self-Determination of Peoples (Oxford: Berg, 1996), 24-25; and Gerry J. Simpson, "The Diffusion of Sovereignty: Self-Determinations in the Post-Colonial Age," in Mortimer Sellers, ed., The New World Order, 48, 54-56.

9. Diane F. Orentlicher, "International Responses to Separatist Claims," 17-18.

10. Quoted by Thurman Arnold, "Criminal Attempts-The Rise and Fall of an Abstraction," Yale Law Journal 40 (1930-31): 58.

11. See for example Daniel Philpott, "Self-Determination in Practice," 92; and Diane F. Orentlicher, "International Responses to Separatist Claims."

12. Hurst Hannum, "Territorial Autonomy: Permanent Solution or Step Toward Secession?" paper presented at the conference on "Facing Ethnic Conflicts: Perspec- 
tives from Research and Policy Making," University of Bonn, 14-16 December 2000, 4.

13. See Saadia Touval, The Boundary Politics of Independent Africa (Cambridge: Harvard University Press, 1972).

14. See Donald L. Horowitz, Ethnic Groups in Conflict (Berkeley: University of California Press, 2000), 281-88; and Donald L. Horowitz, "Irredentas and Secessions: Adjacent Phenomena, Neglected Connections," in Naomi Chazan, ed., Irredentism and International Politics (Studies in International Politics) (Boulder, Colo.: Lynne Rienner, 1991), 9-22.

15. Nicholas Sambanis, "Partition as a Solution to Ethnic War: An Empirical Critique of the Theoretical Literature," World Politics 52 (July 2000): 437-83.

16. See Nicholas Sambanis, "Partition as a Solution to Ethnic War," 479; and Donald L. Horowitz, Ethnic Groups in Conflict, 592-96.

17. Diane F. Orentlicher, "International Responses to Separatist Claims," 14 (emphasis omitted).

18. Diane F. Orentlicher, "International Responses to Separatist Claims," 17.

19. See Thomas M. Franck, "The Emerging Right to Democratic Governance."

20. James Crawford, "State Practice and International Law in Relation to Secession," British Yearbook of International Law 1998 (Oxford: Clarendon Press, 1999), 85-117.

21. James Crawford, "State Practice and International Law in Relation to Secession," 114

22. James Crawford, "State Practice and International Law in Relation to Secession," 115 .

23. James Crawford, "State Practice and International Law in Relation to Secession," 116.

24. Antonio Cassese, "Political Self-Determination."

25. The International Court of Justice has itself recognized periodically that customary international law comprises a limited set of norms to assure coexistence and cooperation among states. See for example Case Concerning Delimitation of the Maritime Boundary in the Gulf of Maine Area, 1984 I.C.J. 246.

26. Karl N. Llewellyn, The Common Law Tradition: Deciding Appeals (Boston: Little, Brown, 1960).

27. Robert Lansing, quoted in David Fromkin, Kosovo Crossing: American Ideals Meet Reality on the Balkan Battlefields (New York: Free Press, 1999), 127.

28. See Arend Lijphart, Democracy in Plural Societies: A Comparative Exploration (New Haven: Yale University Press, 1977).

29. I have written about such devices in various places. See for example Donald L. Horowitz, A Democratic South Africa? Constitutional Engineering in a Divided Society (Berkeley: University of California Press, 1991).

30. See Donald L. Horowitz, "Constitutional Design: An Oxymoron," NOMOS 42 (2000): 253-84. 